\title{
Evaluation of phosphorus sources on performance, organ weight and blood parameters of pigs
}

\author{
Avaliação de fontes de fósforo sobre o desempenho, peso de órgãos e parâmetros \\ sanguíneos em suínos
}

\section{TEIXEIRA, Alexandre de Oliveira ${ }^{1^{*}}$; NOGUEIRA, Eduardo Terra ${ }^{2}$; CORASSA, Anderson $^{3}$; FERREIRA, Vanusa Patrícia de Araújo ${ }^{1}$; ROCHA JÚNIOR, Carlos Magno $^{4}$; LOPES, Darci Clementino ${ }^{4}$}

\author{
${ }^{1}$ Universidade Federal de São João Del Rei. Departamento de Zootecnia. São João del-Rei, Minas \\ Gerais, Brasil. \\ ${ }^{2}$ Ajinomoto do Brasil Ind. e Com. de Alimentos Ltda, Laranjal Paulista, São Paulo, Brasil. \\ ${ }^{3}$ Universidade Federal de Mato Grosso, Instituto de Ciências Agrárias, Sinop, Mato Grosso, Brasil. \\ ${ }^{4}$ Universidade Federal de Viçosa, Departamento de Zootecnia, Viçosa, Minas Gerais, Brasil. \\ *Endereço para correspondência: alexandre_teixeira@ufsj.edu.br
}

\section{SUMMARY}

The objective of this study was to evaluate the effects of different sources of phosphorus on performance, organ weight and blood parameters of pigs. One hundred and twelve pigs with body weight $28.65 \pm 2.82 \mathrm{~kg}$ were distributed into randomized blocks, in a $8 \times 2$ factorial scheme (eight sources of phosphorus $\times$ two sexes), with four repetitions for males and three for females, with two animals per pen. The pigs were fed diets containing: dicalcium phosphate (DCP); monodicalcium phosphate (MCP); triple superphosphate (TS); single superphosphate (SS), Catalão-rock phosphate (ROCK), mix of sources (MIX), phosphoric acid (PAc) or a diet without any supplemental source of phosphorus (CONT). At 60 and $90 \mathrm{~kg}$, all pigs were weighed and blood samples were collected to determine alkaline phosphatase activity (APA), calcium (Ca) and phosphorus (P) and one animal per pen was killed to weigh the liver and kidneys and evaluate carcass yield. The use of diet CONT reduced the weight gain and feed intake, worsened feed:gain ratio and increased the relative weight of the kidneys, APA and $\mathrm{Ca}$, and decreased blood $\mathrm{P}$. The sources DCP, MCP, TS and PAc reduced the APA and maintained the $\mathrm{P}$ and $\mathrm{Ca}$ in the blood constant. Phosphorus sources TS, SS, ROCK and MIX generate similar levels of APA in pigs from 30 to $90 \mathrm{~kg}$ to the diet without inorganic source of phosphorus without affecting their performance.

Keywords: alkaline phosphatase, blood phosphorus, fluorine, kidneys

\section{RESUMO}

O objetivo deste estudo foi avaliar os efeitos de diferentes fontes de fósforo sobre o desempenho, peso de órgãos e parâmetros sanguíneos de suínos. Foram utilizados 112 suínos com peso inicial de $28,65 \pm 2,82 \mathrm{~kg}$ distribuídos em blocos casualizados, em esquema fatorial $8 \times 2$ (oito fontes de fósforo $\mathrm{x}$ dois sexos), com quatro repetições para machos e três para fêmeas com dois animais por baia. Os suínos foram alimentados com dietas contendo:fosfato bicalcico (FBC); fosfato monobicalcico (FMB); superfosfato triplo (ST); superfosfato simples (SS), fosfato de rocha Catalão (ROCHA), mistura de fontes (MIS), ácido fosfórico (AF) ou dieta sem suplementação com fonte de fósforo (CONT). Aos 60 e $90 \mathrm{~kg}$ todos os suínos foram pesados e amostras de sangue fora coletadas para determinação da atividade de fosfatase alcalina (AFA), cálcio $(\mathrm{Ca})$ e fósforo $(\mathrm{P})$ e um animal por baia foi sacrificado para pesagem de fígado 
e rins e avaliação de rendimento de carcaça. A dieta CONT reduziu ganho de peso e consumo, piorou a conversão alimentar e aumentou peso relativo de rins, $\mathrm{AFA}$ e $\mathrm{Ca}$, e diminuiu fósforo sanguíneo. As fontes $\mathrm{FBC}, \mathrm{FMB}, \mathrm{ST}$ e $\mathrm{AF}$ reduziram AFA e mantiveram constante $\mathrm{P}$ e $\mathrm{Ca}$ no sangue. Concluiu-se que fontes de fósforo ST, SS, ROCHA e MIS geraram níveis similares de AFA em suínos de 30 a 90kg que a dieta sem fonte inorgânica de $\mathrm{P}$ sem afetar seu desempenho.

Palavras-chave: flúor, fosfatase alcalina, rins, fósforo sanguíneo

\section{INTRODUCTION}

The demand for animal protein has increased substantially in recent years, causing an intensive increase in production of pig and other domestic species. To improve the productivity and product quality in less time, it is necessary to meet the nutritional requirements of these animals. Among the nutrients required by these animals are the minerals, which have important functions in the body. Minerals are considered essential nutrients to the body, as part of the formation of bones, teeth, muscles, blood and nerve cells, in addition to maintaining the water balance and participating in several biochemical processes of the body.

Among the major minerals, phosphorus is essential for the good performance of an animal and is considered the third most expensive nutrient in pig diets after energy and protein (FAN et al., 2001; SARAIVA et al., 2009 ). Thus, studies focusing on the correct nutritional value of different sources of minerals allow us to use them distinctly according to their marketing costs. Rock phosphates are alternative sources of phosphorus in animal nutrition due to their low cost compared with other phosphates, but it is known that they are not subjected to manufacturing procedures to ensure adequate purity for animals. (SOUZA et al, 2009).

Therefore, the object of study herein was the hypothesis that inclusion of different sources of inorganic phosphorus in pig diets can influence the performance and dynamics of mineral content and specific characteristics in different tissues and in the bloodstream.

Experimentally, many criteria have been used to evaluate the use of inorganic sources of phosphorous in diets for pigs, such as performance, strength, ash, bone mineral deposition, calcium, phosphorus, and alkaline phosphatase in the serum, skeletal abnormalities, phosphorus distribution in the tissues, incorporation rate, phosphorus bioavailability, bone histomorphometry and accumulation of heavy metals in the tissues (FIGUEIREDO et al., 2001).

This study was conducted to evaluate the effects of different sources of phosphorus on performance, blood parameters, carcass, liver weight and kidney weight of pigs.

\section{MATERIAL AND METHODS}

The experiment was carried out at the pig sector of the Department of Animal Science (DZO) at Universidade Federal de Viçosa (UFV), in Viçosa, MG, Brazil, and procedures for humane care and handling of the animals followed the guidelines of Universidade Federal de Viçosa.

A total of 112 pigs with initial weight of $28.65 \pm 2.82 \mathrm{~kg}$ were distributed into randomized blocks, in an $8 \times 2$ factorial scheme (eight sources of phosphorus $\times$ two sexes), with four repetitions for males and three for females and two animals per experimental unit. The initial body weight of the animals was used as a criterion in the formation of blocks. 
The diets were formulated with different sources of phosphorus, as follows: CONT - control diet (without inorganic phosphorus), DCP - control diet + dicalcium phosphate, MCP control diet + monodicalcium phosphate, TS - control diet + triple superphosphate, SS - control diet + single superphosphate, ROCK - control diet + Catalão-rock phosphate, MIX control diet + mix of sources $(65 \%$ TS + $30 \% \mathrm{ROCK}+5 \% \mathrm{PAc}$ ), and PAc control diet + phosphoric acid (Table 1).

Table 1. Composition and relationship between minerals of the phosphorus sources

\begin{tabular}{llcccccc}
\hline \multirow{2}{*}{ Treatments } & \multirow{2}{*}{ Sources of phosphorus } & \multicolumn{6}{c}{ Chemical composition (\%) } \\
\cline { 3 - 8 } & & \multicolumn{1}{c}{$\mathrm{P}^{1}$} & $\mathrm{Ca}^{1}$ & $\mathrm{Mg}^{1}$ & $\mathrm{~F}^{2}$ & $\mathrm{Ca}: \mathrm{P}$ & $\mathrm{P}: \mathrm{F}$ \\
\hline CONT & Vegetable & 0.32 & - & - & 0.001 & - & - \\
DCP & Dicalcium phosphate & 18.66 & 23.25 & 1.34 & 0.17 & 1.25 & 107.9 \\
MCP & Monodicalcium phosphate & 20.29 & 19.50 & 0.81 & 0.19 & 0.96 & 109.1 \\
TS & Triple superphosphate & 20.63 & 16.46 & 0.64 & 1.80 & 0.80 & 11.5 \\
SS & Single superphosphate & 7.62 & 17.20 & 0.57 & 1.01 & 2.26 & 7.5 \\
ROCK & Catalão-rock phosphate & 12.73 & 36.00 & 0.81 & 2.31 & 2.83 & 5.5 \\
MIX & 65\% TS + 30\% ROCK + 5\% PAc & 18.40 & 21.50 & 0.69 & 1.87 & 1.37 & 16.39 \\
PAc & Phosphoric acid & 23.38 & 0.00 & 0.56 & 0.16 & 0.00 & 145.2 \\
\hline
\end{tabular}

${ }^{1}$ Analyses were carried out at Laboratory of Animal Nutrition at Department of Animal Science at UFV.

${ }^{2}$ Analyses were carried out at Laboratory of Rodes Química Cajati LTDA in Cajati - São Paulo.

The diets for the growth (30 to $60 \mathrm{~kg}$ ) and finishing (60 to $90 \mathrm{~kg}$ ) phases were formulated to meet the requirements of animals described by Rostagno et al. (2005).

Animals were weighed at the beginning and end of the experiment and growth $(59.23 \pm 5.55 \mathrm{~kg})$ and finishing phases $(92.75 \pm 9,45 \mathrm{~kg})$, leftover feed and blood samples were collected from all animals of the block to determine the alkaline phosphatase, calcium and phosphorus. In the morning of the visit, blood samples were collected, after fasting four hours, from the vena jugularis of all pigs before feeding for analysis of blood parameters (MORENO et al., 1997). The blood samples were centrifuged and sorum were utilized to quantification of blood parameters as described by Lopes et al. (2009). The levels of alkaline phosphatase, calcium and phosphorus were analyzed using complete sets of reagents for commercial analyses (Table 2).

At the end of each experimental phase, after fasting for 24 hours, one animal per experimental unit, close to the average weight of the block, was killed to weight the liver and kidneys and to evaluate the carcass yield. The carcass yield was calculated by (carcass weight / pre-slaugther weight) x 100 .

The variables were analyzed using the procedures of variance analysis of computer program SAEG version 9.1 (UFV, 2007). In case of difference, the means of the treatments were compared by Student's Newman-Keuls test $(\mathrm{P}<0.05)$. The means of treatments containing different sources of phosphorus were compared with the control treatment (CONT) by Dunnett's test $(\mathrm{P}<$ or $>0.05)$. 


\section{RESULTS AND DISCUSSION}

There was no interaction $(\mathrm{P}>0.05)$ between treatment and sex in any performance parameters and periods. The daily weight gain (DWG), daily feed intake (DFI) and feed:gain ratio (FGR) did not present significant difference $(\mathrm{P}>0.05)$ between treatments with different inorganic sources of phosphorus in the phases of 30 to $60 \mathrm{~kg}$ and 30 to $90 \mathrm{~kg}$ (Table 3 ).

The observation that there was no difference between phosphorus sources for performance in the present study may be explained by the fact that the levels of total phosphorus of the diets were the same among those which had an inorganic source, and assuming that there are differences in the digestibility or availability between sources (TEIXEIRA et al., 2004a), these sources were not sufficient to express difference in animal performance, since the phosphorus requirement for maximum weight gain and feed:gain ratio is less than that for maximum bone mineralization (ALEBRANTE et al., 2011). The similarity between treatments is distinct from that of Souza et al. (2009), in which the performance of the animals was affected by diets supplemented with rock phosphate when compared with dicalciumphosphate diets. Furthermore, similarity in performance between treatments DCP and MCP was also reported by Teixeira et al. (2005).

Animals fed the CONT diet had lower $(\mathrm{P}<0.05)$ DWG in the phase from 30 to $60 \mathrm{~kg}$ than those fed the other diets. Except for the treatment ROCK, other treatments containing inorganic sources of phosphorus presented higher DWG values $(\mathrm{P}<0.05)$ than CONT in the finishing phase. Animals fed the CONT diet had lower DWG from 30 to $60 \mathrm{~kg}$ than those fed the other diets, possibly due to the lower level of phosphorus and high $\mathrm{Ca}: \mathrm{P}$ ratio (2.44) present in this diet compared with the others (1.39). According to Rama Rao et al. (2003), the formation of insoluble complexes of calcium phosphate in the small intestine when there is excess calcium in the diet, associated with the metabolism of both minerals, may cause weight gain and feed efficiency to decrease. Stein et al. (2011) reported that dietary concentrations of $\mathrm{Ca}$ affect the apparent total tract digestibility of phosphorus and that greater utilization of phosphorus is obtained if the diet has a Ca:P ratio around or slightly lower than 1.1:1. Similarly, the NRC (2012) suggests that the ideal $\mathrm{Ca}: \mathrm{P}$ ratio be between 1.1 and 1.25.

The DWG of the ROCK treatment was equal to the CONT treatment from 30 to $90 \mathrm{~kg}$, possibly because, during their growth, the animals used their bone reserves to maintain phosphorus homeostasis, but in the next phase, because the reserves of $\mathrm{P}$ in the bones were reduced and the bioavailability of phosphorus is low in ROCK (TEIXEIRA et al., 2004a), there was limitation in weight gain. This assertion is also based on the findings of Teixeira et al. (2004b), who used similar diets to the present study and stated that the use of diets ROCK and CONT did not provide enough $\mathrm{P}$ to supply the nutritional requirements of pigs, causing the flow of phosphorus of soft tissue and bones to be more intense in order to maintain a stable $\mathrm{P}$ in the bloodstream.

The animals that consumed diet CONT had worse $(\mathrm{P}<0.05)$ feed:gain ratio compared with the other treatments in the phase from 30 to $60 \mathrm{~kg}$, except with respect to treatments DCP and PAc. Moreover, feed:gain ratio was not affected by different sources of phosphorus from 30 to $90 \mathrm{~kg}(\mathrm{P}>0.05)$. 
Table 3. Daily weight gain (DWG), daily feed intake (DFI) and feed:gain ratio (FGR) of pigs fed different sources of phosphorus in the growth and finishing phases according to sex $(\mathrm{M}=$ male; $\mathrm{F}=$ female; $\mathrm{X}=$ mean $)$

\begin{tabular}{|c|c|c|c|c|c|c|c|c|c|c|c|}
\hline \multirow{2}{*}{ Parameters } & \multirow{2}{*}{ Sex } & \multirow{2}{*}{$X$} & \multicolumn{8}{|c|}{ Treatments $^{2}$} & \multirow{2}{*}{$\begin{array}{l}\mathrm{CV} \\
(\%)\end{array}$} \\
\hline & & & CONT & DCP & $\mathrm{MCP}$ & TS & $\mathrm{SS}$ & ROCK & MIX & PAc & \\
\hline \multirow[t]{3}{*}{ DWG $(\mathrm{kg})-30$ to $60 \mathrm{~kg}$} & $\mathrm{M}$ & $0.883^{\mathrm{A}}$ & 0.670 & 0.909 & 0.928 & 0.991 & 0.845 & 0.838 & 0.891 & 0.991 & - \\
\hline & $\mathrm{F}$ & $0.733^{\mathrm{B}}$ & 0.548 & 0.703 & 0.793 & 0.753 & 0.765 & 0.766 & 0.824 & 0.715 & - \\
\hline & $\mathrm{X}$ & 0.808 & 0.618 & $0.821 * *$ & $0.870^{*}$ & $0.889^{*}$ & $0.811^{* *}$ & $0.807^{*}$ & $0.862 * *$ & $0.873^{*}$ & 9.41 \\
\hline \multirow[t]{3}{*}{ DWG $(\mathrm{kg})-30$ to $90 \mathrm{~kg}$} & M & $0.933^{\mathrm{A}}$ & 0.724 & 0.977 & 0.986 & 1.001 & 0.892 & 0.879 & 0.962 & 1.041 & - \\
\hline & $\mathrm{F}$ & $0.784^{\mathrm{B}}$ & 0.599 & 0.812 & 0.894 & 0.817 & 0.819 & 0.753 & 0.809 & 0.766 & - \\
\hline & $\mathrm{X}$ & 0.869 & 0.670 & $0.906^{*}$ & $0.947 *$ & $0.922 *$ & $0.861 * *$ & 0.825 & $0.896^{*}$ & $0.923^{*}$ & 9.77 \\
\hline \multirow[t]{3}{*}{ DFI $(\mathrm{kg})-30$ to $60 \mathrm{~kg}$} & M & $2.078^{\mathrm{A}}$ & 1.747 & 2.130 & 2.145 & 2.166 & 2.024 & 2.004 & 2.117 & 2.291 & - \\
\hline & $\mathrm{F}$ & $1.769^{\mathrm{B}}$ & 1.578 & 1.721 & 1.767 & 1.743 & 1.865 & 1.818 & 1.854 & 1.803 & - \\
\hline & $\mathrm{X}$ & 1.946 & 1.675 & 1.955 & 1.983 & 1.984 & 1.956 & 1.925 & 2.004 & 2.082 & 10.07 \\
\hline \multirow[t]{3}{*}{ DFI (kg) - 30 to $90 \mathrm{~kg}$} & $\mathrm{M}$ & $2.529^{\mathrm{A}}$ & 2.081 & 2.578 & 2.653 & 2.689 & 2.443 & 2.387 & 2.645 & 2.758 & - \\
\hline & $\mathrm{F}$ & 1.949B & 1.673 & 2.021 & 2.011 & 1.877 & 2.077 & 1.930 & 2.019 & 1.984 & - \\
\hline & $\mathrm{X}$ & 2.281 & 1.906 & 2.339 & 2.378 & 2.341 & 2.286 & 2.192 & 2.377 & 2.426 & 9.32 \\
\hline \multirow[t]{3}{*}{ FGR - 30 to $60 \mathrm{~kg}$} & M & $2.399^{\mathrm{B}}$ & 2.631 & 2.468 & 2.379 & 2.207 & 2.410 & 2.370 & 2.393 & 2.330 & - \\
\hline & $\mathrm{F}$ & $2.464^{\mathrm{A}}$ & 2.936 & 2.558 & 2.271 & 2.319 & 2.480 & 2.263 & 2.263 & 2.618 & - \\
\hline & $\mathrm{X}$ & 2.426 & 2.762 & 2.507 & $2.333^{*}$ & $2.255^{*}$ & $2.440 * *$ & $2.324 *$ & $2.337^{*}$ & 2.453 & 8.40 \\
\hline \multirow[t]{3}{*}{ FGR - 30 to $90 \mathrm{~kg}$} & M & $2.739^{\mathrm{A}}$ & 2.886 & 2.654 & 2.730 & 2.695 & 2.759 & 2.746 & 2.782 & 2.658 & - \\
\hline & $\mathrm{F}$ & $2.525^{\mathrm{B}}$ & 2.873 & 2.506 & 2.263 & 2.318 & 2.530 & 2.593 & 2.518 & 2.596 & - \\
\hline & $\mathrm{X}$ & 2.647 & 2.880 & 2.591 & 2.530 & 2.533 & 2.661 & 2.681 & 2.669 & 2.631 & 7.72 \\
\hline
\end{tabular}

${ }^{1}(\mathrm{P}<0.05)$ Means followed by different uppercase letters in the column and different lowercase letters in the row are different by Student-Newman-Keuls' test.

${ }^{2} \mathrm{CONT}=$ control diet; $\mathrm{DCP}=$ dicalcium phosphate; $\mathrm{MCP}=$ monodicalciumphosphate; $\mathrm{TS}=$ triple superphosphate; $\mathrm{SS}=$ single superphosphate; $\mathrm{ROCK}=$ catalão-rock phosphate; MIX = mix of sources; $P$ ac $=$ phosphoric acid.

$*$ Different means $(>$ or $<$ ) relative to diet CONT, by Dunnett's test at $1 \%$.

$* *$ Different means $(>$ or $<$ ) relative to diet CONT, by Dunnett's test at $5 \%$. 
Treatments had no effect of on feed intake in any of the evaluated periods $(\mathrm{P}>0.05)$. The absence of effect of treatments on feed intake was similar to the experiment of Saraiva et al. (2009), who evaluated different levels of phosphorus and maintained the $\mathrm{Ca}: \mathrm{P}$ ratio, and found no differences in feed intake. Similarly to the presented study, Petersen et al. (2011) found no effect of source or level of phosphorus on DFI, FGR or DGW of pigs evaluating diets with DCP and three types of MCP.

The average DWG and DFI were higher $(\mathrm{P}<0.05)$ in males than in females in both phases of evaluation. Feed:gain ratio showed better $(\mathrm{P}<0.05)$ in male pigs during the growth phase, as opposed to that observed in the finishing phase. The results of DWG and DFI in males corroborate those reported by Teixeira et al. (2005), who evaluated the replacement of dicalcium phosphate by monodicalcium phosphate.

The results of absolute and relative weights of liver and kidneys and the results of carcass yield of pigs fed different sources of phosphorus in the growth and finishing phases did not present interaction $(\mathrm{P}>0.05)$ between treatment and sex (Table 4).

Table 4 shows that the experimental diets containing inorganic sources of phosphorus did not influence $(\mathrm{P}>0.05)$ the absolute or relative weights of liver and kidneys; additionally, pigs fed diet CONT had higher $(\mathrm{P}<0.05)$ relative weight of the kidneys compared with the others, although it did not vary $(\mathrm{P}>0.05)$ compared with MCP and SS. Carcass yield was not affected $(\mathrm{P}>0.05)$ by the different sources of phosphorus in the growth and finishing phases (Table 4).

Table 4. Absolute weight (g) and relative weight (\% of carcass) of liver and kidneys and carcass yield of pigs fed different sources of phosphorus in the growth and finishing phases

\begin{tabular}{|c|c|c|c|c|c|c|c|c|c|}
\hline \multirow{2}{*}{ Parameters } & \multicolumn{8}{|c|}{ Treatments $^{2}$} & \multirow{2}{*}{$\begin{array}{l}\text { CV } \\
(\%)\end{array}$} \\
\hline & CONT & DCP & $\mathrm{MCP}$ & TS & $\mathrm{SS}$ & ROCK & MIX & PAc & \\
\hline Liver (kg) & 1.571 & 1.677 & 1.801 & 1.731 & 1.805 & 1.793 & 1.627 & 1.764 & 19.5 \\
\hline Kidneys (kg) & 0.345 & 0.313 & 0.345 & 0.322 & 0.357 & 0.317 & 0.329 & 0.308 & 11.8 \\
\hline Relative weight liver (\%) & 1.926 & 1.866 & 1.892 & 1.832 & 1.960 & 1.969 & 1.719 & 1.874 & 18.0 \\
\hline Relative weight kidneys (\%) & 0.424 & $0.348 *$ & 0.364 & $0.340 *$ & 0.388 & $0.348 *$ & $0.348^{*}$ & $0.329^{*}$ & 11.9 \\
\hline Carcass yield $(\%)$ & 73.49 & 72.21 & 72.77 & 72.72 & 73.95 & 73.92 & 73.49 & 73.34 & 3.5 \\
\hline
\end{tabular}

The liver and kidneys are important organs in the metabolism of phosphorus in the body, whose metabolization is faster than in the bone (ANNENKOV, 1982), so the increase in the relative weight of the kidneys in pigs on CONT may be related to increased of excretion activity exerted by the body due to the excess calcium caused by the high $\mathrm{Ca}: \mathrm{P}$ ratio in diet CONT and excess sulfur 
from SS. Evaluating the same mineral sources, Moreira et al. (2009) reported that urinary losses were affected by phosphorus sources, whose lowest values were obtained in the control diet, monodicalcium phosphate, dicalcium phosphate and Catalão-rock and the highest values were obtained for phosphoric acid, single superphosphate and triple superphosphate. The higher urinary excretions suggest that the absorption of dietary phosphorus may have exceeded the metabolic requirements of the animals, proportionally decreasing the incorporation of phosphorus in bones and tissues. In the present study, the absolute and relative weights of organs of pigs at $90 \mathrm{~kg}$ body weight did not differ between DCP and MCP, as also observed by Teixeira et al. (2005).

Absence of effect of different phosphorus sources on carcass yield would be expected since no different responses were observed for DWG during the growth and finishing phases, confirming the findings of Varley et al. (2011), who compared different strategies for phosphorus supplementation, and Teixeira et al. (2005), who evaluated DCP and MCP.

There was no interaction $(\mathrm{P}>0.05)$ between treatment and sex for calcium (Ca), phosphorus (P) and alkaline phosphatase (AP) in the blood serum of pigs at 60 and $90 \mathrm{~kg}$ (Table 5). The blood alkaline phosphatase activity of the animals fed DCP, MCP and PAc were lower $(\mathrm{P}<0.05)$ than the CONT treatment (at 60 and $90 \mathrm{~kg}$ ) and treatment MIX (to $60 \mathrm{~kg}$ ), but did not differ from the others.

Alkaline phosphatase is an enzyme that catalyzes the hydrolysis of phosphate esters with half life in the blood of 24 to 48 hours. Although the extent of its activity involves variety of isoenzymes that originate from the intestines, kidneys, pancreas, placenta, liver and bone, the two largest sources of this enzyme are bone (osteoblasts) and liver (endothelial cells). The elevated levels of blood alkaline phosphatase activity of the CONT (at 60 and $90 \mathrm{~kg}$ ) and MIX (at $60 \mathrm{~kg}$ ) is treatments probably related to their participation in bone resorption.

According to Veloso (1991), the mechanism of action of alkaline phosphatase begins with low levels of calcium and phosphorus in the diet, which determine low blood levels. It then follows the process of bone resorption. Concomitantly, there is need for rebuilding bone, which stimulates the activity of osteoblasts. The increased activity of osteoblasts implies increased of alkaline phosphatase secretion, which, in turn, acts increasing the inorganic phosphorus concentration adjacent to the affected bone region and stimulates the collagen tissue to deposit calcium.

The results in the Table 5 showed that control diet promoted lower $\mathrm{P}$ content $(\mathrm{P}<0.05)$ in the blood serum of animals at 60 and $90 \mathrm{~kg}$ compared with the other treatments. In the present experiment, the $\mathrm{P}$ concentration in the blood serum of animals at $60 \mathrm{~kg}$ did not differ between the inorganic sources, while treatment MIX displayed greater content $(\mathrm{P}<0.05)$ than the diet containing DCP for $90 \mathrm{~kg}$ animals, but did not differ from other inorganic sources.

According to Moreira et al. (2009) the consumption of feeds deficient in phosphorus can cause increased bone resorption and promote temporary increase in plasma phosphorus concentration and increased endogenous losses and urinary losses, but in the present study, only the pigs of treatment MIX had greater P concentration in the blood serum that those on DCP. 
Table 5. Levels of alkaline phosphatase (AP), phosphorus (P) and calcium (Ca) in the blood serum of pigs from 60 and $90 \mathrm{~kg}$ fed diets containing different sources of phosphorus, according to $\operatorname{sex}(\mathrm{M}=$ male; $\mathrm{F}=$ female; $\mathrm{X}=$ overall mean $)$

\begin{tabular}{|c|c|c|c|c|c|c|c|c|c|c|c|}
\hline \multirow{2}{*}{ Parameters } & \multirow{2}{*}{ Sex } & \multirow{2}{*}{$\mathrm{X}$} & \multicolumn{8}{|c|}{ Treatments $^{2}$} & \multirow{2}{*}{$\mathrm{CV}(\%)$} \\
\hline & & & CONT & DCP & $\mathrm{MCP}$ & $\mathrm{TS}$ & $\mathrm{SS}$ & ROCK & MIX & PAc & \\
\hline \multirow{3}{*}{ AP - 60kg (IU) } & $\mathrm{M}$ & $478.7^{\mathrm{B}}$ & 473.1 & 405.9 & 409.3 & 555.4 & 515.5 & 492.9 & 575.4 & 402.3 & - \\
\hline & $\mathrm{F}$ & $534.2^{\mathrm{A}}$ & 659.5 & 492.3 & 409.7 & 498.3 & 573.3 & 584.8 & 661.7 & 393.8 & - \\
\hline & $\mathrm{X}$ & 502.5 & 553.0 & $442.9^{\mathrm{b} * *}$ & $409.4^{\mathrm{b} *}$ & $530.9^{\mathrm{ab}}$ & $540.3^{\mathrm{ab}}$ & $532.3^{\mathrm{ab}}$ & $612.4^{\mathrm{a}}$ & $398.6^{\mathrm{b} * *}$ & 16.70 \\
\hline \multirow{3}{*}{ AP - 90kg (IU) } & M & 439.6 & 540.9 & 381.1 & 414.5 & 472.5 & 431.1 & 461.3 & 451.1 & 363.9 & - \\
\hline & $\mathrm{F}$ & 475.7 & 601.7 & 516.3 & 391.8 & 428.0 & 511.3 & 506.5 & 493.8 & 356.5 & - \\
\hline & $\mathrm{X}$ & 455.1 & 566.9 & $439.1 * *$ & $404.8^{*}$ & 453.4 & 465.5 & 480.6 & 469.4 & $360.7^{*}$ & 16.27 \\
\hline \multirow{3}{*}{$\mathrm{P}-60 \mathrm{~kg}(\mathrm{mg} / \mathrm{dl})$} & M & $8.91^{\mathrm{B}}$ & 5.46 & 9.09 & 8.50 & 9.67 & 9.77 & 9.40 & 9.59 & 9.83 & - \\
\hline & $\mathrm{F}$ & $9.58^{\mathrm{A}}$ & 5.60 & 9.69 & 9.23 & 10.17 & 10.95 & 10.51 & 10.36 & 10.14 & - \\
\hline & $\mathrm{X}$ & 9.20 & 5.52 & $9.35 *$ & $8.81 *$ & $9.88^{*}$ & $10.27 *$ & $9.87 *$ & $9.92 *$ & $9.96 *$ & 8.91 \\
\hline \multirow{3}{*}{$\mathrm{P}-90 \mathrm{~kg}(\mathrm{mg} / \mathrm{dl})$} & M & 8.72 & 6.16 & 8.40 & 8.51 & 9.43 & 9.30 & 9.21 & 9.98 & 8.79 & - \\
\hline & $\mathrm{F}$ & 9.12 & 5.93 & 8.38 & 9.04 & 10.16 & 10.13 & 9.85 & 10.01 & 9.48 & - \\
\hline & $\mathrm{X}$ & 8.89 & 6.06 & $8.39^{\mathrm{b} *}$ & $8.74^{\mathrm{ab} *}$ & $9.74^{\mathrm{ab} *}$ & $9.65^{\mathrm{ab} *}$ & $9.48^{\mathrm{ab} *}$ & $9.99^{\mathrm{a} *}$ & $9.09^{\mathrm{ab} *}$ & 9.04 \\
\hline \multirow{3}{*}{$\mathrm{Ca}-60 \mathrm{~kg}(\mathrm{mg} / \mathrm{dL})$} & M & $12.61^{\mathrm{B}}$ & 13.86 & 12.36 & 12.42 & 12.39 & 12.51 & 12.08 & 12.76 & 12.48 & - \\
\hline & $\mathrm{F}$ & $13.92^{\mathrm{A}}$ & 14.80 & 13.72 & 13.52 & 13.56 & 14.23 & 13.68 & 13.72 & 14.10 & - \\
\hline & $\mathrm{X}$ & 13.17 & 14.26 & 12.94 & 12.89 & 12.89 & 13.25 & 12.77 & 13.17 & 13.17 & 6.24 \\
\hline \multirow{3}{*}{$\mathrm{Ca}-90 \mathrm{~kg}(\mathrm{mg} / \mathrm{dL})$} & M & 13.58 & 14.14 & 13.66 & 13.31 & 13.51 & 13.35 & 13.74 & 13.24 & 13.71 & - \\
\hline & $\mathrm{F}$ & 14.08 & 15.95 & 14.03 & 13.52 & 13.65 & 14.08 & 13.72 & 13.63 & 14.08 & - \\
\hline & $\mathrm{X}$ & 13.80 & 14.91 & $13.82 * *$ & $13.40 *$ & $13.57^{*}$ & $13.66^{*}$ & $13.73 * *$ & $13.41 *$ & 13.87 & 3.68 \\
\hline
\end{tabular}

${ }^{1}(\mathrm{P}<0.05)$ Means followed by different uppercase letters in the column and different lowercase letters in the row are different by Student-Newman-Keuls' test.

${ }^{2} \mathrm{CONT}=$ control diet; $\mathrm{DCP}=$ dicalcium phosphate; $\mathrm{MCP}=$ monodicalcium phosphate; $\mathrm{TS}=$ triple superphosphate; $\mathrm{SS}=$ single superphosphate; $\mathrm{ROCK}=$ catalão-rock phosphate;

MIX $=$ mix of sources; $\mathrm{Pac}=$ phosphoric acid.

*Different means $(>$ or $<$ ) relative to diet CONT (negative control), by Dunnett's test at $1 \%$

**Different means $(>$ or $<$ ) relative to diet CONT (negative control), by Dunnett's test at $15 \%$. 
These observations are consistent with Moreira et al. (2010), who characterized the metabolism of phosphorus in pigs and reported that in the flow of phosphorus from the gastrointestinal tract into the plasma the values were similar for the same inorganic sources of phosphorus of this experiment and lower for the control diet.

Similar to differences in the P content of control pigs of others treatments with inorganic phosphorus sources at 60 and 90kg, Koch \& Mahan (1986) found a linear effect on phosphorus concentration in the blood serum of finishing pigs fed increasing levels of phosphorus. They also verified hypophosphatemia in piglets fed diets deficient in phosphorus, reaching a minimum $\mathrm{P}$ value of around 34 at 41 days of restriction of the mineral, as a consequence of depletion of the labile reserves of the element in the reserve phosphorus tissues of the animal.

The $\mathrm{Ca}$ content in the blood serum of animals at 60 and $90 \mathrm{~kg}$ was not affected $(\mathrm{P}>0.05)$ by the phopshorus sources in animal diets. The $\mathrm{Ca}$ content in the blood serum of animals to $90 \mathrm{~kg}$, was higher $(\mathrm{P}<0.05)$ in animals fed diet CONT compared with animals fed diets containing supplemental phosphorus sources, except for the diet PAc. The resorption is dependent on the levels of $\mathrm{Ca}$ and $\mathrm{P}$ in blood. If the blood $\mathrm{Ca}$ level is decreased, the bone resorption is increased to maintain the $\mathrm{Ca}$ level steady (LOPES et al., 2009).

Males at $60 \mathrm{~kg}$ had lower $(\mathrm{P}<0.05)$ alkaline phosphatase activity, phosphorus and calcium content in blood serum, but sex had no effect on the blood parameters of pigs at $90 \mathrm{~kg}$ of body weight. The levels of alkaline phosphatase, phosphorus and calcium in blood serum of pigs to $90 \mathrm{~kg}$ did not differ between males and females; however, they were higher in females at $60 \mathrm{~kg}$, which is in agreement with the observations of Teixeira et al. (2005), who evaluated diets with DCP and MCP.

Pigs from 30 to $90 \mathrm{~kg}$ fed diets without inorganic source of phosphorus have lower levels of $\mathrm{Ca}$ and $\mathrm{P}$ and higher levels of alkaline phosphatase in the blood serum and increased relative weight of kidneys, expressing worse performance than those fed inorganic sources of phosphorus. Thus, diets without inorganic source of phosphorus prejudice the performance and blood parameters in pigs from 30 to $90 \mathrm{~kg}$. Males showed better performance that females from 30 to $60 \mathrm{~kg}$ however worse calcium and phosphorus blood levels.

The sources of phosphorus single superphosphate, triple superphosphate, Catalão-rock phosphate and mix of sources generated similar levels of alkaline phosphatase in pigs from 30 to $90 \mathrm{~kg}$ to the diet without inorganic source of phosphorus without affecting their performance, but pigs fed Catalãorock phosphate had their daily weight gain limited.

\section{REFERENCES}

ALEBRANTE, L.; DONZELE, J.L.; OLIVEIRA, R.F.M.; SARAIVA, A.; GUIMARÃES, S.E.F.; FERREIRA, A.S. Available phosphorus levels in diets for pigs with high genetic potential for lean meat deposition kept in thermoneutral environment from 15 to $30 \mathrm{~kg}$. Revista Brasileira de

Zootecnia, v.40, n.2, p.323-330, 2011.

ANNENKOV, B.N. Kinetics of mineral metabolism in blood. In:

GEORGIEVSKII, V.I.; ANNENKOV, B.N.; SAMOKHIN, V.I. (Eds.) Mineral nutrition of animals. 1.ed. London: Butterworths, 1982. p. 243-253. 
FAN, M.Z.; ARCHBOLD, T.; SAUER, W.C.; LACKEYRAM, D.; RIDEOUT, T.; GAO, Y.; DE LANGE, C.F.M.; HACKER, R.R. Novel methodology allows simultaneous measurement of true phosphorus digestibility and gastrointestinal endogenous phosphorus outputs in studies with pigs. Journal of Nutrition, v.131, n.9, p.2388-2396, 2001.

FIGUEIREDO, A.V.; VITTI, D.M.S.S.; LOPES, J.B.; BARBOSA, H.P.

Disponibilidade biológica do fósforo de fontes fosfatadas determinada por intermédio da técnica de diluição isotópica. II. Suínos em crescimento. Revista Brasileira de Zootecnia, v.30, n.5, p.1514-1520, 2001.

KOCH, M.E.; MAHAN, D.C. Biological characteristics for assessing low phosphorus intake in finishing swine.

Journal of Animal Science, v.62, p.163$172,1986$.

LOPES J.B.; VITTI, D.M.S.S.; ABDALLA, A.L.; HADDAD, M.L.; FIGUEIREDO, A.V.; MORAES, R.C.B. Modelo do fluxo biológico do fósforo de fontes de fosfato em suínos, usando o 32P como marcador. Revista Brasileira de Zootecnia, v.30, n.1, p.165-173, 2001.

LOPES, J.B.; MOREIRA, J.A.; KEBREAB, E.; VITTI, D.M.S.S.; ABDALLA, A.L.; CROMPTON, L.A.; FRANCE, J. A model on biological flow of phosphorus in growing pigs. Arquivo Brasileiro de Medicina Veterinária e Zootecnia, v.61, n.3, p.691-697, 2009.

MOREIRA, J.A.; VITTI, D.M.S.S.; TEIXEIRA, A.O.; LOPES, J.B.

Comparação e aplicação de dois modelos matemáticos no estudo do metabolismo de fósforo em suíno. Revista Brasileira de Zootecnia, v.39, n.10, p.2222-2229, 2010.
MOREIRA, J.A.; VITTI, D.M.S.S.; TEIXEIRA, A.O.; LOPES, J.B. Fisiologia digestiva de suínos alimentados com rações contendo diferentes fontes de fósforo. Revista Brasileira de Zootecnia, v.38, n.4, p.676-684, 2009.

MORENO, A.M.; SOBESTIANSKY, J.; LOPEZ, A.C.; SOBESTIANSKY, A.A.B. Colheita e processamento de amostras de sangue em suínos para fins de diagnóstico. Concórdia: EMPRAPA-CNPSA, 1997. 30p. (Documentos, 41).

NATIONAL RESEARCH COUNCIL NRC. Nutrient Requirements of

Swine. $11^{\text {th }}$ revised edition.

Washington, DC: National Academy of Science, 2012.

PETERSEN, G.I.; PEDERSEN, C.; LINDEMANN, M.D.; STEIN, H.H. Relative bioavailability of phosphorus in inorganic phosphorus sources fed to growing pigs. Journal of Animal Science, v.89, p.460-466, 2011.

RAMA RAO, S.V.; PANDA, A.K.; RAJU, M.V.L.N.; SHYAM SUNDER, G.; PRAHARAJ, N.K. Requirement of calcium for commercial broilers and white leghorn layers at low dietary phosphorus levels. Animal Feed Science and Technology, v.106, n1-4, p.199-208, 2003.

ROSTAGNO, H.S.; ALBINO, L.F.T.; DONZELE, J.L.; GOMES, P.C.; OLIVEIRA, R.F.; LOPES, D.C.; FERREIRA, A.S.; BARRETO, S.L.T. Tabelas brasileiras para aves $\mathrm{e}$ suínos: composição de alimentos e exigências nutricionais. 3.ed. Viçosa, MG: Universidade Federal de Vilosa, 2005. 186p. 
SARAIVA, A.; DONZELE, J.L.; OLIVEIRA, R.F.M.; ABREU, M.L.T.; SILVA, F.C.O.; HAESE, D. Níveis de fósforo disponível em rações para suínos de alto potencial genético para deposição de carne dos 30 aos $60 \mathrm{~kg}$. Revista Brasileira de Zootecnia, v.38, n.7, p.1279-1285, 2009.

STEIN, H.H.; ADEOLA, O.; CROMWELL, G.L.; KIM, S.W.; MAHAN, D.C.; MILLER, P.S. Concentration of dietary calcium supplied by calcium carbonate does not affect the apparent total tract digestibility of calcium, but decreases digestibility of phosphorus by growing pigs. Journal of Animal Science, v.89, p.2139-2144, 2011.

SOUZA, L.W.O.; MORETTI, A.S.; TUCCI, F.M.; SOUZA, N.H.; LEAL, P.A.M.; ANZAI, N.H. Phosphorus availability of rock phosphates as compared with feed-grade phosphates for swine. Revista Brasileira de Zootecnia, v.38, n.1, p.90-98, 2009.

TEIXEIRA, A.L.; LOPES, D.C.; GOMES, P.C.; LOPES, J.B.; COSTA, L.F.; FERREIRA, V.P.A.; PENA, S.M.; MOREIRA, J.A.; BÜNZEN, S. Níveis de substituição do fosfato bicálcico pelo monobicálcico em dietas para suínos nas fases de crescimento e terminação. Revista Brasileira de Zootecnia, v.34, n.1, p.142-150, 2005.

TEIXEIRA, A.L.; LOPES, D.C.; LOPES, J.B.; VITTI, D.M.S.S.; GOMES, P.C.; ROSTAGNO, H.S.; MOREIRA, J.A.; INACIO, F. Determinação da biodisponibilidade do fósforo de diferentes fontes pela técnica de diluição isotópica, em suínos em crescimento. Revista Brasileira de Zootecnia, v.33, n.5, p.1231-1237, 2004a.
TEIXEIRA, A.L.; LOPES, D.C.; VITTI, D.M.S.S.; LOPES, J.B.; GOMES, P.C.; MOREIRA, J.A.; PENA, S.M.; TEIXEIRA, M.P. Estimativas do fluxo de fósforo entre os compartimentos anatômicos e fisiológicos de suínos alimentados com dietas contendo diferentes fontes de fósforo. Revista Brasileira de Zootecnia, v.33, n.5, p.1246-1253, 2004b.

\section{UNIVERSIDADE FEDERAL DE VIÇOSA - UFV. SAEG 9.1: Sistema} de Análises Estatística. Viçosa, MG: Fundação Arthur Bernardes, 2007.

VARLEY, P.F.; SWEENEY, T.; RYAN, M.T.; O'DOHERTY, J.V. The effect of phosphorus restriction during the weaner-grower phase on compensatory growth, serum osteocalcin and bone mineralization in gilts. Livestock Science, v.135, p.282288, 2011.

VELOSO, J.A.F. Perspectiva de uso dos fosfatos de rocha nacionais na alimentação animal. Caderno técnico da Escola de Veterinária da UFMG, v.6, p.55-84, 1991.

Data de recebimento: $26 / 07 / 2013$

Data de aprovação: 23/12/2013 